\title{
PAEDIATRIC OROFACIAL TUMOURS: NEW ORAL HEALTH CON- CERN IN PAEDIATRIC PATIENTS
}

\author{
F.O. OMOREGIE and O. AKPATA \\ University of Benin Teaching Hospital, Department of Oral Pathology/Oral Medicine, PMB 1111 , Benin, Edo \\ State, 300001Nigeria.
}

DOI: http://dx.doi.org/10.4314/gmj.v48i1.2

Corresponding Author: Dr. Felix O. Omoregie

Email: omoregiefo@yahoo.com

Conflict of interest: None declared

\section{SUMMARY}

Objective: This study aims to determine the incidence, age, gender, orofacial sites and histological pattern of paediatric orofacial tumours in a Nigerian population. The yearly findings will be analysed to identify the interval for increase in the incidence of paediatric orofacial tumours.

Patients and Methods: A 21-year (1990 to 2010) retrospective analysis of paediatric orofacial tumours in children younger than 16 years was carried out in the Department of Oral Pathology/Oral Medicine, University of Benin Teaching Hospital, Benin City, Nigeria.

Results: Of the 1013 diagnosed lesions within the study period, there were 137 (13.5\%) paediatric orofacial tumours, among which $71(51.8 \%)$ cases occurred within the last 6 years (2005 to 2010). There was male predilection for the lesions (78 males to 59 females, ratio $=1.3: 1)$. The mean age was $9+4.3$ years, with peak age group of 11 to 15 years $(n=60,43.8 \%)$. The mandible $(\mathrm{n}=44,32.1 \%)$, followed by the maxilla $(n=42,30.7 \%)$ and orofacial soft tissue $(n=19,13.9 \%)$ were the most common sites. The benign tumours $(\mathrm{n}=72,52.6 \%)$ were slightly more than the malignant tumours $(\mathrm{n}=65,47.4 \%)$. There were more malignant tumours $(\mathrm{n}=23,16.8 \%)$ than benign tumours $(\mathrm{n}=20$, $14.6 \%$ ) within the last 3 years (2008 to 2010) under review. Burkitt's lymphoma $(\mathrm{n}=38,27.7 \%)$ was the commonest malignant lesion.

Conclusion: This study showed a recent increase in the incidence of paediatric orofacial tumours, particularly due to a higher incidence of Burkitt's lymphoma.

Keywords: Paediatrics, Orofacial tumour, Benign, Malignant, Oral Health

\section{INTRODUCTION}

Previous reports show that the incidence of paediatric orofacial tumours was relatively low, $(9.1 \%$ to $10.7 \%)$. It consists predominantly of benign tumours $(91 \%$ to $97.1 \%$ ), while malignant tumours constitute $2.9 \%$ to $9 \%{ }^{1-3}$ However, recent reports from Nigerian studies show an increasing incidence of paediatric orofacial tumours $(24 \% \text { to } 28 \%)^{4,5}$ in our environment.

A higher incidence of malignant orofacial tumours among paediatric patients is also reported among Nigerians by Ajayi et al4 in Lagos (13.3\%) and Omoregie et $\mathrm{al}^{6}$ in Benin (22.5\%). Furthermore, Aregbesola et al ${ }^{5}$ reported a higher incidence of malignant paediatric orofacial tumour $(51 \%)$ than the benign tumours $(49 \%)$.

Malignant lesions are a cause of oral health concern in children even with the current effort to control communicable diseases in the third world countries. ${ }^{7}$ In our environment they rank fourth as a cause of mortality. ${ }^{8}$ Orofacial malignancies are of great concern because of the associated high mortality due to late presentation for treatment, ${ }^{9,10}$ a low 5-year survival rate $(55 \%){ }^{11}$ poverty, lack of awareness and local beliefs. ${ }^{12}$ Moreover, paediatric orofacial tumours whether benign or malignant may be associated with facial disfigurement with associated psychosocial problems. ${ }^{13-15}$

So far, no study in our environment has evaluated the incidence of paediatric tumours with a view to determine if there is an increase incidence of these lesions over a given period. Also, the specific clinicodemographic factors and histological pattern of the lesions within a surge period is yet to be determined. This study aims to determine the incidence, age, gender, orofacial sites and histological pattern of paediatric orofacial tumours in a Nigerian population. It also aims to analyse the yearly findings in order to establish the incidence of the lesions during the study period.

\section{METHODS}

Ethical approval was obtained from the Hospital Ethical Committee to carry out a 21-year (1990 to 2010) retrospective analysis of all paediatric orofacial tumours seen in children younger than 16 years, in the Department of Oral Pathology/Oral Medicine, University of Benin Teaching Hospital, Benin City, Nigeria. 
This hospital serves as a major referral health centre in the south-south region of Nigeria and receives specimens from other hospitals in the city and parts of the South-East and South-West of Nigeria.

The incidence, age, gender, sites and histopathological patterns of paediatric orofacial tumours were obtained from the records of cases and histopathology registers. The histopathology slides of paediatric patients seen within the 21-year study period were reviewed. The data collected were analyzed using SPSS version ${ }^{16}$ and statistical correlation of the variables was per-formed using Pearson's Chi-square, with a confidence level of $95 \%$ and probability values ( $p$-value) of $\mathrm{P}<0.05$ regarded as significant.

\section{RESULTS}

Of the 1013 diagnosed lesions within the study period, there were $137(13.5 \%)$ paediatric orofacial tumours. There was male predilection for the lesions (78 males to 59 females, ratio of 1.3:1). The mean age was $9+$ 4.3 years, with overall peak age group of 11 to 15 years $(n=60,43.8 \%)$ and the peak year was $2008(n=23,16.8$ $\%)$. The mandible $(\mathrm{n}=44,32.1 \%)$, followed by the maxilla $(n=42,30.7 \%)$ and orofacial soft tissue $(n=19$, $13.9 \%$ ) were the most common sites. (Table 1)

Most of the lesions were non-odontogenic tumours $(n=116,84.7 \%)$ and the benign tumours $(n=72,52.6 \%)$ were slightly more than the malignant tumours $(n=65$, 47.4\%) [Tables 1, 2, 3 and 4]. Seventy-one (51.8\%) cases among the 137 paediatric tumours were diagnosed within the last 6 years (2005 to 2010) of the study, occurring predominantly in males (48 males to 23 females, ratio $=2: 1)$ and in the jaws $(n=47,34.3 \%)$ (Table 5).

The malignant tumours $(n=23,16.8 \%)$ were slightly more than benign tumours $(n=20,14.6 \%)$ within the last 3 years (2008 to 2010) under review. The benign tumours were mostly ameloblastoma $(n=15,10.9 \%)$ with $6(4.4 \%)$ cases occurring in the last 6 years; followed by juvenile ossifying fibroma $(n=11,8.0 \%)$ and fibrous dysplasia $(n=10,7.3 \%)$. While Burkitt's lymphoma $(n=38,27.7 \%)$ and diffuse non-Hodgkin's lymphoma $(n=13,9.5 \%)$ were the commonest malignant lesions. Twenty-five $(18.3 \%)$ cases of the Burkitt's lymphomas and $7(5.1 \%)$ cases of diffuse nonHodgkin's lymphoma occurred in the last 6 years. (Table 6)

There was significant association of the paediatric orofacial tumours for males and the jaws $(p<0.05)$, especially within the last 6 years under review. There was significant association of Burkitt's lymphoma as the predominant paediatric orofacial tumour within the last 6 years under review $(\mathrm{p}<0.05)$.

Table 1 Age, gender and orofacial site distribution of paediatric orofacial tumours

\begin{tabular}{|l|l|l|l|l|l|l|l|l|l|}
\hline Age group & $\begin{array}{l}\text { Benign } \\
\text { Tumour }\end{array}$ & $\begin{array}{l}\text { Malignant } \\
\text { Tumour }\end{array}$ & Total & $\mathbf{\%}$ & Gender & $\begin{array}{l}\text { Benign } \\
\text { Tumour }\end{array}$ & $\begin{array}{l}\text { Malig- } \\
\text { nant } \\
\text { Tumour }\end{array}$ & Total & \% \\
\hline $0-5$ & 13 & 20 & 33 & 24.1 & Male & 42 & 36 & 78 & 56.1 \\
\hline $6-10$ & 14 & 30 & 44 & 32.1 & Female & 30 & 29 & 59 & 43.1 \\
\hline $11-15$ & 45 & 15 & 60 & 43.8 & & & & & \\
\hline Total & $\mathbf{7 2}$ & $\mathbf{6 5}$ & $\mathbf{1 3 7}$ & $\mathbf{1 0 0}$ & Total & $\mathbf{7 2}$ & $\mathbf{6 5}$ & $\mathbf{1 3 7}$ & $\mathbf{1 0 0}$ \\
\hline & & & & & & & & & \\
\hline Orofacial Sites & & $\begin{array}{l}\text { Benign } \\
\text { Tumour }\end{array}$ & & $\begin{array}{l}\text { Malignant } \\
\text { Tumour }\end{array}$ & & Total & $\mathbf{\%}$ & & \\
\hline Mandible & & 28 & & 16 & & 44 & 32.1 & & \\
\hline Maxilla & & 16 & & 26 & & 42 & 30.7 & & \\
\hline Soft Tissue & & 7 & & 12 & & 19 & 13.9 & & \\
\hline Parotid & & 3 & & - & & 3 & 2.2 & & \\
\hline Gingivae & & 10 & & 1 & & 11 & 8.0 & & \\
\hline Palate & & 10 & & 1 & & 4 & 2.9 & & \\
\hline Submandibular & & 2 & & 1 & & 2 & 1.5 & & \\
\hline Sublingual & & 2 & & - & & 2 & 1.5 & & \\
\hline $\begin{array}{l}\text { Mandible- } \\
\text { Maxilla }\end{array}$ & & - & & 7 & & 7 & 5.1 & & \\
\hline Facial/Scalp skin & & 1 & & 1 & & 1 & 1.5 & & \\
\hline Total & & $\mathbf{7 2}$ & & $\mathbf{6 5}$ & & $\mathbf{1 3 7}$ & $\mathbf{1 0 0}$ & & \\
\hline
\end{tabular}


Table 2 Histopathologic types of the paediatric orofacial benign tumours

\begin{tabular}{|l|l|l|}
\hline Non-odontogenic tumours & Frequency & $\mathbf{\%}$ \\
\hline Fibrous dysplasia & 10 & 7.3 \\
\hline Juvenile ossigying Fibroma & 11 & 8.0 \\
\hline Pyogenic granuloma & 5 & 3.7 \\
\hline Haemamgionna & 4 & 2.9 \\
\hline Granular cell tumour & 3 & 2.2 \\
\hline Peripheral ossifying Fibroma & 5 & 3.7 \\
\hline Centrl giant cell Granuloma & 3 & 2.2 \\
\hline Teratoma & 1 & 0.7 \\
\hline Lipoma & 1 & 0.7 \\
\hline Adenolmphoma & 1 & 1.5 \\
\hline Pleomorphic adenoma & 2 & 0.7 \\
\hline Melanocytic neuroectodemal & 1 & 2.2 \\
\hline Periapical granuloma & 3 & 0.7 \\
\hline Fibroepithelial polyp & 1 & 0.7 \\
\hline Sub-total & $\mathbf{5 1}$ & $\mathbf{3 7 . 2}$ \\
\hline Odontogenic tumours & Frequency & $\mathbf{\%}$ \\
\hline Ameloblastoma & 15 & 11.0 \\
\hline Odontongenic fibromyxoma & 2 & 1.5 \\
\hline Odontome & 1 & 0.7 \\
\hline Ameloblastic fibroma & 1 & 0.7 \\
\hline Peripheral odontogenic fibroma & 1 & 0.7 \\
\hline $\begin{array}{l}\text { Adenomatoid odontogenic tu- } \\
\text { mour }\end{array}$ & 1 & 0.7 \\
\hline Sub-total & 21 & 15.3 \\
\hline TOTAL & $\mathbf{7 2}$ & $\mathbf{5 2 . 5}$ \\
\hline
\end{tabular}

Table 3 Histopathologic types of the paediatric orofacial malignant tumours

\begin{tabular}{|l|l|l|}
\hline Malignant Tumour & Frequency & $\mathbf{\%}$ \\
\hline Burkitt's lymphoma & 38 & 27.7 \\
\hline Embryonic rhabdomyosarcoma & 4 & 2.9 \\
\hline Non-Hodgkin lymphoma & 13 & 9.5 \\
\hline Squamous cell carcinoma & 2 & 1.5 \\
\hline Giant cell tumour & 1 & 0.7 \\
\hline Mucoepidermoid carcinoma & 2 & 1.5 \\
\hline Neuroblastoma & 1 & 0.7 \\
\hline Chondrasarcoma & 1 & 0.7 \\
\hline Malignant fibrous histocytoma & 2 & 1.5 \\
\hline $\begin{array}{l}\text { Polymorphous-low grade ade- } \\
\text { nocarcinoma }\end{array}$ & $\mathbf{1}$ & $\mathbf{0 . 7}$ \\
\hline Total & $\mathbf{6 5}$ & $\mathbf{4 5 . 5}$ \\
\hline
\end{tabular}

Table 4 Distribution of the benign and malignant paediatric orofacial tumours by years

\begin{tabular}{|l|l|l|l|l|}
\hline Years & $\begin{array}{l}\text { Benign } \\
\text { Tumour }\end{array}$ & $\begin{array}{l}\text { Malignant } \\
\text { Tumour }\end{array}$ & Frequency & \% \\
\hline $\begin{array}{l}1990 \text { to } \\
1994\end{array}$ & 20 & 11 & 31 & 22.6 \\
\hline $\begin{array}{l}1995 \text { to } \\
1999\end{array}$ & 6 & 6 & 12 & 8.8 \\
\hline $\begin{array}{l}2000 \\
\text { to2004 }\end{array}$ & 11 & 12 & 23 & 16.8 \\
\hline $\begin{array}{l}2005 \text { to } \\
2010\end{array}$ & 35 & 36 & 71 & 51.8 \\
\hline Total & $\mathbf{7 2}$ & $\mathbf{6 5}$ & $\mathbf{1 3 7}$ & $\mathbf{1 0 0}$ \\
\hline
\end{tabular}

Table 5 Gender and orofacial sites distribution of paediatric orofacial tumour from 2005 to 2010

\begin{tabular}{|c|c|c|c|c|c|c|c|c|}
\hline \multirow[t]{2}{*}{ GENDER } & \multicolumn{8}{|c|}{ YEAR } \\
\hline & 2005 & 2006 & 2007 & 2008 & 2009 & 2010 & Total & $\%$ \\
\hline Male & 10 & 5 & 6 & 13 & 6 & 8 & 48 & 35.0 \\
\hline Female & 3 & 2 & 2 & 10 & 3 & 3 & 23 & 16.8 \\
\hline Total & 13 & 7 & 8 & 23 & 9 & 11 & 71 & 51.8 \\
\hline \multicolumn{9}{|l|}{ Orofacial Sites } \\
\hline Mandible & 7 & 1 & 1 & 5 & 5 & 5 & 24 & 17.5 \\
\hline Maxilla & 5 & 1 & 2 & 12 & 1 & 2 & 23 & 16.8 \\
\hline Soft Tissue & - & 1 & 2 & - & 2 & 1 & 6 & 4.4 \\
\hline Gingivae & - & 1 & 1 & 3 & - & 1 & 6 & 4.4 \\
\hline Palate & 1 & - & 1 & - & - & 1 & 3 & 2.2 \\
\hline Submandibular & - & - & - & 1 & - & - & 1 & 0.7 \\
\hline Mandible-Maxilla & - & 2 & 1 & 2 & - & 1 & 6 & 4.4 \\
\hline Facial/scalp skin & - & 1 & - & - & 1 & - & 2 & 1.4 \\
\hline Total & 13 & 7 & 8 & 23 & 9 & 11 & 71 & 51.8 \\
\hline
\end{tabular}


Table 6 Histopathologic types of paediatric orofacial tumour from 2005 to 2010

\begin{tabular}{|c|c|c|c|c|c|c|c|}
\hline \multirow{2}{*}{$\begin{array}{l}\text { HISTOPATHOLOGIC } \\
\text { TYPE } \\
\text { Benign Tumours } \\
\end{array}$} & \multicolumn{7}{|c|}{ YEARS } \\
\hline & 2005 & 2006 & 2007 & 2008 & 2009 & 2010 & total \\
\hline Ameloblastoma & 1 & - & - & 2 & 3 & - & 6 \\
\hline Odontogenic fibromyxoma & 1 & - & - & - & - & - & 1 \\
\hline Odontome & 1 & - & 1 & - & - & - & 2 \\
\hline $\begin{array}{lll}\begin{array}{l}\text { Peripheral odontogenic fi- } \\
\text { broma }\end{array} & \\
\end{array}$ & - & 1 & - & - & - & - & 1 \\
\hline Fibrous dysplasia & - & - & - & 2 & 1 & 1 & 4 \\
\hline Juvenile ossigying fibroma & - & - & 1 & - & - & 1 & 2 \\
\hline Pyogenic granuloma & - & - & - & - & - & 1 & 1 \\
\hline Haemangioma & - & 1 & - & - & 1 & - & 2 \\
\hline Granular cell tumour & 2 & - & - & - & - & - & 2 \\
\hline Peripheral ossifying fibroma & - & 1 & 1 & 2 & - & - & 4 \\
\hline Central giant cell granuloma & - & - & 1 & 2 & 2 & - & 5 \\
\hline Lipoma & - & - & - & 1 & - & - & 1 \\
\hline Periapical granuloma & 3 & - & - & - & - & - & 3 \\
\hline Fibroepithelial & - & - & - & - & - & 1 & 1 \\
\hline \multicolumn{8}{|l|}{ Malignant tumours } \\
\hline Burkitt's lymphoma & 4 & 4 & 3 & 12 & 1 & 1 & 25 \\
\hline Non-hodgkin lymphoma & 1 & - & - & 1 & - & 5 & 7 \\
\hline Squamous cell carcinoma & - & - & - & 1 & - & - & 1 \\
\hline Chondrosarcoma & - & - & 1 & - & - & - & 1 \\
\hline $\begin{array}{l}\text { Malignant fibrous histocyto- } \\
\text { ma }\end{array}$ & - & - & - & - & 1 & - & 1 \\
\hline $\begin{array}{l}\text { Polymorphous low grade } \\
\text { adenocarcinoma }\end{array}$ & - & - & - & - & - & 1 & 1 \\
\hline Total & 13 & 7 & 8 & 23 & 9 & 11 & 71 \\
\hline Percentage & 9.5 & 5.1 & 5.8 & 16.8 & 6.6 & 8.0 & 51.8 \\
\hline
\end{tabular}

\section{DISCUSSION}

Several reports ${ }^{1-3,16}$ between year 1996 and 2000 showed a relatively low incidence of paediatric orofacial tumours, which suggests that the lesions did not constitute great risk to oral health of children about a decade ago, compared to dental caries that was regard-

ed as the highest oral health concern among paediatric patients. ${ }^{17}$ Recent studies among black African population shows an increasing incidence of malignant paediatric orofacial tumours, and has apparently raised oral health concerns for these population. ${ }^{18}$ This study was carried out among a population in the South-South zone of Nigeria and a similar pattern of increased incidence (13.5\%) of paediatric orofacial tumours though relatively, with predilection for males and the jaws, and peak age range of 11 to 15 years was observed, especially within the last 6 years under review.
This study showed a predominant non-odontogenic paediatric orofacial tumour, with a narrowing of the gap between the incidence of benign tumours (52.6\%) and malignant tumours (47.4\%). Furthermore, a slight-ly higher incidence of malignant tumours (16.8\%), compared to benign tumours (14.6\%) was observed in the last 3 years (2008 to 2010) of the study. Burkitt lymphoma accounted mainly for the increase incidence of paediatric orofacial tumour observed within the last 6 years of the study, with a peak inci-dence in 2008.

Although a reduction in Burkitt lymphoma was observed in the last 2 years (2009 and 2010) of the study, the increase incidence of paediatric orofacial tumour in 2009 and 2010 were mainly due to ameloblastoma and diffuse nonHodgkin lymphoma respectively. This study agrees with the recent report of a higher incidence of malignant paediatric orofacial tumours in our environment by Aregbesola et al. ${ }^{5}$ On the contrary, a recent African study by Elarbi et al, reported a lower incidence of malignant paediatric orofacial tumour in Libyan children. ${ }^{18}$ 
Therefore, the in-creasing incidence of malignant paediatric orofacial tumours and the attendant increase in oral health concerns appears not to be wide spread in Africa, but more pronounced in our environment.

The histopathologic pattern of the paediatric orofacial tumours studied showed that Burkitt's lymphoma was the commonest malignant lesion, while ameloblastoma was the commonest benign tumour. These tumours also accounted for most of the lesions within the 6-year surge period for paediatric orofacial tumours observed in this study. Similarly, previous studies ${ }^{4-6,16}$ in our environment reported that Burkitt's lymphoma was the predominant malignant paediatric orofacial tumour.

It appears that the increase in oral health concerns for paediatric orofacial tumour in our environment may be primarily due to increase in the incidence of Burkitt's lymphoma. The reasons for this finding may not be unconnected with the poor control of infections by Epstein Barr virus (EBV) and plasmodium falciparum (malaria parasite), which are the two infections strongly associated with the pathogenesis of Burkitt's lymphoma. ${ }^{19,20}$ However, it was reported that funding to control malaria in sub-Saharan Africa has increased between 1999 and $2004 .^{21}$ Apart from controlling repeated attacks of malaria, the molecular genetics of Burkitt's lymphoma need to be revisited. This is because the known sites of chromosomal translocation may not be the only sites where mutations in the Blymphocytes now occur. Furthermore, there are reports suggesting that variation in the pattern of chromosomal mutation in endemic and sporadic Burkitt's lymphoma 22, as well as the rapid accumulation of p53 protein in both EBV positive and negative B-lymphocytes ${ }^{23,24}$ may be the other factors involved the development of Burkitt's lymphoma.

In our environment, other possible factors that may have contributed to increase in the incidence of paediatric orofacial tumours include; increase public awareness about oral health care and the establishment of more oral health care centres, with more specialist diagnosticians and improved diagnostic facilities for orofacial disease.

In conclusion, this study showed a recent increase in the incidence of paediatric orofacial tumours particu-larly in the jaws and among males, due to a higher incidence of Burkitt's lymphomas among other possible factors recognized in our environment. However, larger prospective studies are re- quired to determine if the finding in our Centre is applicable to the general paedi-atric population. This study suggests a higher oral health concerns for Burkitt's lymphoma among paedi-atric patients. We therefore recommend a more efficient utilization of the available funds for control of malaria infection, to help reduce the rapid rate of development of Burkitt's lymphoma in our environment.

\section{REFERENCE}

1. Sato M, Tanaka N, Sato T, Amagasa T Oral and maxillofacial tumours in children: a review Br J Oral Maxillofac Surg. 1997;35(2):92-5.

2. Tanaka N, Murata A, Yamaguchi A, Kohama G. Clinical features and management of oral and maxillofacial tumors in children. Oral Surg Oral Med Oral Pathol Oral Radiol Endod. 1999 Jul;88 (1):11-5.

3. Maaita JK. Oral tumors in children: a review. J Clin Pediatr Dent. 2000 Winter; 24(2):133-5.

4. Ajayi OF, Adeyemo WL, Ladeinde AL, Ogunlewe $\mathrm{MO}$, et al. Malignant orofacial neoplasms in children and adolescents: a clinicopathologic re-view of cases in a Nigerian tertiary hospital. Int J Pediatr Otorhinolaryngol. 2007 Jun;71(6):959-63.

5. Aregbesola SB, Ugboko VI, Akinwande JA, Arole $\mathrm{GF}$, et al. Orofacial tumours in suburban Nigerian children and adolescents. Br J Oral Maxillofac Surg. 2005 Jun;43(3):226-31.

6. Omoregie FO, Igbe AP, Ojo MA. Childhood oro-facial malignancies in Nigerians. Ann. Biomed Sci. 2009; 8(2): 75-81

7. Ekanem I A, Asindi A A, Ekwere P D, Ikpatt N W, et al. Malignant childhood tumours in Calabar, Nigeria. Afr. J. Med. Sci. 1992; 21(2): 62-9.

8. Akang E E U, Asinobi A O, Fatunde O J, Pindiga H U, Okpala J U, et al. Childhood mortality in Ibadan: an autopsy study. Nig. J. Paediatrics 1992; 19(2): 30-6.

9. Arotiba JT, Adebola RA, Ajike SO, Adeola DS, et al. Orofacial Tumours and Tumour-like lesions in Kano, Nigeria. Nig J Surg Research 2003;5(3-4): 134-9.

10. Tobias JS. Cancer of the head and neck. $\mathrm{Br}$ Med $J$ 1994; 308 (6934):961-6

11. Johnson NW. Orofacial neoplasm: Global epidemiology, risk factors and recommendations for research. Int dent. J. 1991; 41: 367-75

12. Adeola DS, Obiadaze AC. Orofacial carcinoma in Kaduna. Nig J Surg Research 2006; 8(3-5): 144-7.

13. Ajagbe HA, Daramola JO. Primary tumours of the jaw in Nigerian children. J Nat Med Associa 1982, 74: 157-161.

14. Parkins GEA, Armah G, Ampofo P. Tumours and tumour-like lesions of the lower face in Korle Bu Teaching Hospital, Ghana - an eight year study. World $J$ Surg Oncol 2007; 5:48 doi:10.1186/1477-7819-5-48.

15. Banon J N, Saad M N. Operative plastic and reconstructive surgery. Edinburgh, London Mel-bourne and New York, Churchill Living Stone, 1980; pp5-6. 
16. Arotiba GT. A study of orofacial tumors in Nigerian children. J Oral Maxillofac Surg. 1996 ;54(1):34-9.

17. Schneider D, Crall JJ. EPSDT Periodicity Sched-ules and their Relation to Pediatric Oral Health Standards in Head Start and Early Head Start: A Technical Issue Brief by National Oral Health Policy Center, June 2005, pp1-12.

18. Elarbi M, El-Gehani R, Subhashraj K, Orafi M. Orofacial tumors in Libyan children and adoles-cents. A descriptive study of 213 cases. Int $J$ Pe-diatr Otorhinolaryngol 2009 ;73(2):237-42

19. Shiramizu B, Barriga F, Neequaye J, Jafri A. Pat-terns of chromosomal breakpoint locations in Burkitt's lymphoma: relevance to geography and Epstein-Barr virus association. Blood, 1991; 77: 1516-1526.
20. Geser A, de Thé G, Lenoir G, Day NE, et al. Final case reporting from the Ugandan prospective study of the relationship between EBV and Burkitt's Lymphoma. Int Journal of Cancer. 1982; 29: 397-400.

21. Waddington C, Martin J, Walford V. Prepared for the Roll Back Malaria Partnership. Trends in International Funding for Malaria Control. August 2005, pp 1-28

22. Klein U, Klein G, Ehlin-Henriksson B, Rajewsky K, et al. Burkitt's Lymphoma Is a Malignancy of Mature B Cells Expressing Somatically Mutated V Region Genes Molec Med. 1995;5: 495-505

23. Paul JF, Gordon JA, Frances S, Karen HV et al. p53 is frequently mutated in Burkitt's lymphoma cell lines. EMBO J. 1991; 10(10): 2879-2887.

24. Kalungi S, Wabinga H, Bostad L. The RB (pRb2/p16) and p53 (p14/p53/p21) Tumor-suppressor Pathways in Endemic Burkitt Lym-phoma. $J$ Pediatr Hematol/Oncol. 2011; 33 (2) 54-59. 